\title{
TINGKAT KESIAPSIAGAAN MASYARAKAT DIBIDANG KESEHATAN DALAM MENGHADAPI DAMPAK ERUPSI GUNUNG BERAPI
}

\author{
Al Afik ${ }^{1}$, Azizah Khoriyati ${ }^{2}$, Ilham Yoga Pratama ${ }^{3}$ \\ 1,2,3 Universitas Muhammadiyah Yogyakarta \\ E-mail : afik72@umy.ac.id
}

\begin{abstract}
Communities living in volcanic disaster prone areas (DPA) have a high risk of being affected if an eruption occurs. The health impacts including of shortness of breath due to volcanic dust, physical and psychological injuries, burns, and inhalation trauma that can result in fatalities. This study aimed to determine the community mitigation factor, especially the health sector in facing the impact of volcanic eruptions. study used correlational descriptions with a purposive sampling technique. Regarding this, we used 219 respondents in Srunen Galagahharjo Cangkringan Sleman Yogyakarta as the sample. The data were collected by distributing questionnaires using google form. Furthermore, we used Spearman analysis to examine the mitigation in the health sector in facing the volcanic eruptions impact. The general disaster mitigation of the Srunen Hamlet residents (which categorized in DPA III level) were divided into several levels: advanced (43\%); moderate (51.6\%); and poor (4.6\%). Meanwhile, the health mitigation divided into several levels: advanced (23.3\%); moderate (70.3\%); and poor (6.4\%). Regarding this, there was a significant relationship between training activity and the level of community mitigation, with $p$ value $=0.004$ and $r$ value $=0.288$. The level of community mitigation in the health sector in facing the volcanic eruptions impact was in the moderate category and there was a relationship between training for residents and the level of community mitigation. Eventually, there was a need to improve community mitigation, especially in the health sector by continuously holding mitigation trainings to prevent risks from the volcanic eruptions impact.
\end{abstract}

Keywords : Health sector mitigation, Mitigation, Volcanic eruption disaster

Abstrak : Masyarakat yang tinggal di kawasan rawan bencana (KRB) gunung berapi memiliki risiko besar terdampak apabila terjadi erupsi. Dampak Kesehatan terutama dari mulai terjadinya sesak nafas akibat debu vulkanik, cedera fisik dan psikologis, luka bakar, trauma inhalasi sampai terjadinya kegawatdaruratan sehingga dapat mengakibatkan korban jiwa. Tujuan penelitian ini adalah untuk mengetahui faktor kesiapsiagaan masyarakat terutama bidang Kesehatan dalam menghadapi dampak erupsi gunung api. Deskrisi korelasional, dengan jumlah sampel 219 responden warga dusun Srunen Galagahharjo Cangkringan Sleman Yogyakarta dengan tehnik purposive sampling, data diambil dengan membagikan quisioner dengan sarana google form. Analisis kesiapsiagaan umum dan bidang Kesehatan terhadap dampak erupsi gunung api dengan analisis sperman. Tingkat kesiapsiagaan secara umum warga Dusun Srunen (KRB III) kategori baik (43\%), cukup (51,6\%), kurang 4,6\%, tingkat kesiapsiagaan kesehatan kategori baik(23,3\%), cukup(70,3\%), kurang $(6,4 \%)$, terdapat hubungan yang signifikan dengan nilai $p$ value $=0,04$, dengan nilai $r=0,288$, antara pelatihan dengan tingkat kesiapsiagaan warga. Tingkat kesiapsiagaan masyarakat dalam bidang kesehatan terhadap dampak erupsi gunung api dalam kategori cukup dan terdapat hubungan antara pelatihan bagi warga dengan tingkat kesiapasigaan masyarakat. Perlunya upaya untuk meningkatkan kesiapsiagaan warga terutama dibidang Kesehatan dengan terus secara kontinyu diadakan pelatihan-pelatihan terkait mitigasi kesiapsiagaan untuk mencegah risiko dari dampak erupsi gunung api.

Kata Kunci : Kesiapsiagaan, Kesiapsiagaan bidang kesehatan, bencana Erupsi Gunung Api

\section{PENDAHULUAN}

Kesiapsiagaan yaitu merencanakan tindakan untuk merespon ketika terjadi bencana. Kesiapsiagaan juga bisa diartikan sebagai keadaan dimana keadaan orang atau masyarakat siap siaga dalam menghadapi bencana atau keadaan darurat (Adiwijaya, 2017). Sikap yang dilaksanakan untuk mengantisipasi kemungkingan terjadinya bencana untuk menghindari terjadinya korban jiwa, kerugian harta benda, dan berubahnya tata kehidupan masyarakat yaitu sikap kesiapsiagaan (Ni Made, et al., 2018).

Upaya kesiapsiagaan untuk menghadapi bencana dengan melibatkan Stakeholder utama seperti individu, rumah tangga, dan pemerintah. Stakeholder pendukung seperti kelembagaan masyarakat (PKK, karangtaruna, majelis taklim, dll). Individu dan rumah tangga 
merupakan ujung tombak, subjek, dan objek dari kesiapsiagaan yang langsung berpengaruh terhadap resiko bencana. Kelompok rentan yang beresiko lebih tinggi dari dampak bencana yaitu wanita, anakanak, lansia dan orang cacat (NDMA, 2014).

Tahun 2007 dan tahun 2014 Gunung Kelud erupsi dengan perubahan frekuensi yang diakibatkan oleh terbentuknya kubah lava di mulut kawah gunung. Letusan ini bersifat eksplosif dengan VEI (Volcano Explosivity Index) maksimal 4 dan berlangsung singkat yaitu 2 hari atau kurang, kecuali letusan pada tahun 1990 dan 2007. Tahun 2014 letusan Gunung Kelud menyebabkan 56.089 korban jiwa di 89 titik yang tersebar di beberapa Kabupaten yaitu Kabupaten Kediri, Kota Batu, Kabupaten Blitar, Kabupaten Malang, dan Kabupaten Jombang (Sugara, et al, 2018).

Tahun 1994 letusan Gunung Merapi secara tiba-tiba mengeluarkan lahar yang mengalir pada lembah daerah Turgo dan akhirnya menempa acara pernikahan di bukit Turgo yang mengakibatkan 54 tewas dan 81 orang dilarikan ke Rumah Sakit untuk diberikan penanganan intensif luka bakar. Letusan besar Gunung Merapi pada tahun 2010 puncak meletus tanggal 5 November 2010 mengarah kesungai Gendol, memakan korban kurang lebih 200 orang tewas akibat letusan pada daerah

\section{METODE PENELITIAN}

Penelitian ini menggunakan metode kuantitatif deskriptif korelasional. Penelitian ini dilakukan untuk mengetahui sejauh mana kesiapsiagaan terutama bidang kesehatan pada masyarakat di lereng gunung Merapi yaitu di Dusun Srunen Desa Glagaharjo Cangkringan kabupaten Sleman Daerah Istimewa Yogyakarta dalam menghadapi bencana erupsi gunung berapi. Populasi berjumlah 475 orang adalah warga dusun Srunen. Sampel ditentukan dengan menggunakan Simple random sampling, dengan jumlah sampel sebanyak 219 kepala keluarga. Kuisioner dibagikan melalui sarana google form dalam jaringan, Instrumen Penelitian ini menggunakan skala Gutman. Skala pengukuran ini digunakan untuk mendapatkan jawab yang tegas yaitu "ya" yang sedang dilakukan evakuasi massal oleh pemerintah (Baxter \& Horwell, 2015).

Jumlah korban jiwa pada erupsi Gunung Merapi tahun 2010 di KRB III tercatat sebanyak 260 jiwa, yang tersebar di beberapa Desa seperti Desa Glagaharjo, Desa Argomulyo, Desa Umbulharjo, Desa Wukirsari dan Desa Argomulyo. Korban di wilayah KRB III kebanyakan diakibatkan oleh ancaman utama erupsi merapi yaitu awan panas dan beberapa akibat kecelakaan dan penyakit (Sari, 2017).

Secara umum warga Dusun Srunen Glagaharjo sudah menyadari terkait bahaya erupsi Gunung Merapi. Dibuktikan dengan pengalaman erupsi tahun 2010 dan erupsi freatik tahun 2018 warga sudah melakukan evakuasi mandiri. Sebagian warga Dusun Srunen pernah mengikuti pelatihan dan simulasi terkait penanggulangan bencana erupsi Merapi namun belum semua mendapatkan pelatihan dan edukasi terkait kesiapsiagaan kesehatan dalam menghadapi bencana Erupsi Merapi.

Dari catatan dampak yang ditimbulkan oleh erupsi gunung api terutama dampak Kesehatan lebih spesifik terjadinya kegawatdaruratan yang diakibatkan oleh awan panas, abu vulkanik, lahar panas dan atau banjir lahar dingin, maka perlunya diketahui tingkat kesiapan Masyarakat secara umum dan khususnya kesiapan dalam bidang Kesehatan.

atau "tidak". Jawaban diberi skor tertinggi 1 dan terendah 0 yang berarti jawaban "ya" skor 1 dan jawaban "tidak" skor 0 (Sugiyono , 2016). Penilaian pada penelitian ini skor 1 setiap menjawab pertanyaan "ya" pada pertanyaan favorable dan skor 1 setiap menjawab pertanyaan "tidak" pada pertanyaan unfavorable. Variable kesiapsiagaan warga secara umum dan lebih sepsifik kesiapsiagaan bidang Kesehatan. Analisis pada penelitian ini menggunakan analisis univariat tentang tingkat pengetahuan kesiapsiagaan masyarakat secara umum dan kesiapan di bidang Kesehatan terhadap bencana erupsi gunung berapi. Analisis bivariat dalam penelitian ini menggunakan uji korelasi Spearman. Uji korelasi digunakan untuk menghubungkan antar variabel pelatihan / 
simulasi penanganan bencana Erupsi kesiapsiagaan.

Gunung Berapi dengan tingkat

\section{HASIL PENELITIAN}

Hasil dari pengambilan data kepada warga di Dusun Srunen Glagaharjo Cangkringan kabupaten Sleman Propinsi Daerah Istimewa Yogyakarta yang merupakan wilayah KRB III Gunung Merapi, yang merupakan daerah yang terdampak ketika terjadi erupsi dalam setiap periode.

Tabel 1 Karakteristik Responden

\begin{tabular}{lcc}
\hline Karakteristik Responden & Frekuensi (n) & Presentase (\%) \\
\hline Jenis Kelamin & & \\
Laki - Laki & 127 & 58 \\
Perempuan & 92 & 42 \\
Usia & & \\
18-20 Tahun & 12 & 5,5 \\
$21-40$ Tahun & 194 & 88,6 \\
41-60 Tahun & 13 & 5,9 \\
Pendidikan & & \\
SD & 6 & 2,7 \\
SMP & 14 & 6,4 \\
SMA/SMK & 196 & 89,4 \\
Perguruan Tinggi & 3 & 1,4 \\
Pekerjaan & & \\
Petani/Peternak/buruh & 175 & 80 \\
Wiraswasta & 24 & 11 \\
PNS,TNI,POLRI & 6 & 2,7 \\
Belum Bekerja & 15 & 6,8 \\
Pernah Mengikuti Pelatihan Simulasi Bencana & & 68,49 \\
Pernah & 150 & 31,50 \\
Belum Pernah & 69 & $\mathbf{1 0 0 \%}$ \\
\hline
\end{tabular}

Dari tabel 1 di atas menunjukkan bahwa responden terbanyak adalah rentang usia $21-40$ tahun $(88,6 \%)$ dengan perbandingan laki-laki lebih banyak dari perempuan yaitu 127 orang (58\%). Jenjang pendidikan $89,4 \%$ tingkat SMA/SMK dan didominasi sebagai peternak, petani dan atau buruh tani sebesar 175 orang (80\%). Warga Srunen ini sebanyak 150 orang (68,49\%) pernah mengikuti pelatihan dan atau simulasi penaggulangan bencana erupsi gunung api yang diselenggarakan oleh pemerintah daerah kabupaten Sleman.

Tabel 2 Tingkat Kesiapsiagaan Menghadapi Bencana Erupsi Gunung Api

\begin{tabular}{lcc}
\hline Kategori & Frekuensi (n) & Presentase (\%) \\
\hline Baik & 96 & 43 \\
Cukup & 113 & 51,6 \\
Kurang & 10 & 4,6 \\
\hline
\end{tabular}

Tabel 2. Menjelaskan tingkat kesiapsiagaan secara umum warga terhadap dampak bencana erupsi gunung api dalam kategori cukup yaitu sebanyak 113 warga(51,6\%). 
Tabel 3 Indikator Kesiapsiagaan Secara Umum

\begin{tabular}{clccc}
\hline No & \multicolumn{1}{c}{$\begin{array}{c}\text { Komponen Kesiapan } \\
\text { Mengetahui dan tersedia: }\end{array}$} & Benar & Salah & $\%$ \\
\hline 1 & Status Level Vulkanik & 192 & 27 & 87,7 \\
2 & Daerah KRB & 149 & 70 & 68 \\
3 & Arah angin & 151 & 68 & 68,9 \\
4 & $\begin{array}{l}\text { Titik kumpul, rambu dan jalur } \\
\text { evakuasi }\end{array}$ & 165 & 54 & 75,3 \\
5 & $\begin{array}{l}\text { Terdapat peringatan dini } \\
\text { Keluarga ada tas siaga bencana }\end{array}$ & 158 & 61 & 72,1 \\
$\quad \begin{array}{l}\text { untuk dokumen dan barang } \\
\text { penting }\end{array}$ & & & \\
6 & $\begin{array}{l}\text { Akan tetap berada di rumah ketika } \\
\text { erupsi }\end{array}$ & 164 & 55 & 74,9 \\
7 & $\begin{array}{l}\text { Akan mengenakan pakaian } \\
\text { pelindung }\end{array}$ & 180 & 39 & 82,2 \\
8 & $\begin{array}{l}\text { Akan mengetahui wilayah abu dan } \\
\text { vulkanik dan daerah rawan lain }\end{array}$ & 155 & 64 & 70,8 \\
9 & $\begin{array}{l}\text { Hanya membawa barang penting } \\
\text { ketika mengungsi }\end{array}$ & 166 & 54 & 75,8 \\
10 & $\begin{array}{l}\text { Bila ada barang yang tertinggal } \\
\text { akan segera mengambil }\end{array}$ & 153 & 66 & 77,6 \\
\hline
\end{tabular}

Tabel 3. Diatas menyajikan indikator dari responden dalam komponen kesiapsiagaan secara umum dengan parameter tertinggi pada pemahaman aspek status level vulkanik, yaitu jawaban benar sebanyak $87,7 \%$, dan terendah pada pemahaman mengenai daerah Kawasan risiko bencana (KRB) yaitu sebesar 68\% dari 219 responden.

Tabel 4. Tingkat Kesiapsiagaan Bidang Kesehatan $(n=219)$

\begin{tabular}{lcc}
\hline Kategori & Frekuensi (n) & Presentase (\%) \\
\hline Baik & 51 & 23.3 \\
Cukup & 154 & 70.3 \\
Kurang & 14 & 6.4 \\
\hline
\end{tabular}

Tabel 4. Menunjukkan hasil yaitu tingkat kesiapan warga dibidang Kesehatan dalam kategori cukup yaitu berjumlah 154 orang atau sebesar $70,3 \%$ dari 219 responden.

Tabel 5. Indikator Kesiapsiagaan Bidang Kesehatan ( $\mathrm{N}=\mathbf{2 1 9})$

\begin{tabular}{clccc}
\hline No & \multicolumn{1}{c}{ Komponen Kesiapsiagaan Kesehatan } & Benar & Salah & $\%$ \\
\hline 1 & $\begin{array}{l}\text { Ada kader kesehatan dan sudah terlatih } \\
\text { pertolongan pertama pada kondisi kegawatan. }\end{array}$ & 193 & 26 & 88 \\
2 & $\begin{array}{l}\text { Pernah mengikuti pelatihan pertolongan pertama } \\
\text { pada kecelakaan. }\end{array}$ & 182 & 37 & 83,1 \\
$3 \quad \begin{array}{l}\text { Tokoh masyarakat, kaum muda, kelompo } \\
\text { krentan di desa saya pernah diberikan } \\
\text { sosialisasi Kesehatan }\end{array}$ & 172 & 69,5 \\
$4 \quad \begin{array}{l}\text { Pernah melakukan / mengikuti simulasi erupsi } \\
\text { gunung berapi terkait kesehatan } \\
\text { Keluarga menyepakati bahwa yang didahulukan } \\
\text { untuk ditolong adalah anggota keluarga rentan, } \\
\text { seperti lansia, orang dengan penyakitk ronis, } \\
\text { anak anak, ibu hamil, dan orang dengan } \\
\text { kebutuhan khusus. }\end{array}$ & 150 & 63 & 71,2 \\
$\begin{array}{l}\text { Menyimpan dengan baik alat-alat kebutuhan } \\
\text { khusus untuk usia rentan, seperti kacamata, alat } \\
\text { bantu jalan, obat obatan penyakit kronis, dll }\end{array}$ & 138 & 81 & 63 \\
\hline
\end{tabular}




\begin{tabular}{clccc}
\hline No & Komponen Kesiapsiagaan Kesehatan & Benar & Salah & \% \\
\hline 7 & Dirumah terdapat kotak P3K & 117 & 102 & 53,4 \\
8 & $\begin{array}{l}\text { Di kotak P3K saya terdapat set perawatan luka. } \\
\text { (perban steril, sarung tangan bersih, perban } \\
\text { segitiga, antiseptik, obat luka, dan kain } \\
\text { pembalut) }\end{array}$ & 114 & 105 & 52,1 \\
\hline
\end{tabular}

Tabel 5 Kesiapsiagaan bidang Kesehatan terhadap dampak erupsi gunung api prosentase tertinggi ada pada indikator pemahaman adanya kader terlatih untuk dapat melakukan pertolongan pertama pada kondisi kegawatan yaitu sebanyak 193 orang (88\%) dan terendah pada pemahaman kelengkapan isi kotak P3 sebanyak 114 orang $(52,1 \%)$.

Tabel 6. Distribusi Frekuensi Warga Pernah dan Tidak Pernah Pelatihan/Simulasi

\begin{tabular}{lcccccc}
\hline \multicolumn{1}{c}{ Kategori } & \multicolumn{2}{c}{ Baik } & \multicolumn{2}{c}{ Cukup } & \multicolumn{2}{c}{ Kurang } \\
& $\mathrm{n}$ & $\%$ & $\mathrm{~N}$ & $\%$ & $\mathrm{n}$ & $\%$ \\
\hline Pernah pelatihan / simulasi & 65 & 43,3 & 84 & 56 & 1 & 0,7 \\
Tidak pernah pelatihan / simulasi & 11 & 15,9 & 53 & 76,8 & 5 & 7,2 \\
\hline
\end{tabular}

Tabel 6 di atas menunjukkan bahwa warga masyarakat yang pernah mengikuti pelatihan simulasi bencana erupsi gunung api, tingkat kesiapannya mayoritas dalam kategori cukup yaitu sebesar 84 (56\%).

Tabel 7. Hubungan pengalaman mengikuti pelatihan / simulasi dengan tingkat kesiapsiagaan

\begin{tabular}{llcc}
\hline No & Variabel & \multicolumn{2}{c}{ Tingkat Kesiapsiagaan } \\
\cline { 3 - 4 } & & $\mathrm{R}$ & $\mathrm{P}$ \\
\hline 1 & Tidak pernah pelatihan & -0.163 & 0.04 \\
\hline
\end{tabular}

Tabel 7 Menunjukkan nilai uji korelasi penelitian bahwa terdapat hubungan yang signifikan dengan nilai $p$ value $=0,04$ dengan nilai $r=-0,163$, Hal tersebut menunjukkan bahwa pelatihan berhubungan dengan tingkat kesiapsiagaan masyarakat menghadapi bencana erupsi Gunung Berapi Merapi.

\section{PEMBAHASAN}

Tingkat kesiapan masyarakat di lereng gunung Merapi yaitu di dusun Srunen Glagahharjo Cangkringan Sleman DIY, yang merupakan daerah KRB III di dapatkan hasil sebagai berikut :

\section{Karakteristik Demografi Responden} Mayoritas responden yaitu laki-laki dengan jumlah 124 orang atau sekitar $56,6 \%$. Pada penelitian ini sebagian besar responden berjenis kelamin laki-laki dikarenakan penyebaran kuesioner yang menggunakan google form dibagikan kepada grup whatsApp perkumpulan bapakbapak dan grup karang taruna. Penelitian ini sejalan dengan penelitian Setyaningrum \& Rumagutawan, (2018) yang mayoritas responden adalah laki-laki sebanyak 57 orang dengan persentase $100 \%$, Laki-laki merupakan sosok pemimpin dalam keluarga, yang bertanggungjawab dalam kebutuhan sehari-hari, pengambil keputusan dan sebagai tulang punggung keluarga yang harus bertindak denganbijak, tindakan yang bijak akan membuat anggota keluarga menjadi aman dan nyaman. Dalam penelitian ini sosok laki-laki akan lebih tertarik karena membahas hal-hal yang bersifat penting bagi warga yang menetap di KRB (Kawasan Resiko Bencana) dalam penentuan kebijakan yang akan membuat keluarga menjadi aman dan nyaman.

Pada penelitian ini mayoritas usia responden termasuk dalam kategori dewasa awal. Menurut Hurlock (2011) rentang usia 21 - 40 tahun memasuki kategori usia dewasa awal. Hal ini berkaitan dengan penyebaran kuesioner yang 
dilakukan oleh peneliti yang menggunakan google form yang disebarkan pada grupwhatsApp. Penelitian ini menggunakan media google form yang mengharuskan responden mengakses internet menggunakan hand phone atau alat elektronik lain dan terhubung ke internet. Generasi millennial atau generasi y yang lahir di antara tahun 1980-1995, atau saat ini berumur antara 25 sampai 40 tahun. Generasi ini banyak menggunakan teknologi yang terhubung internet karena hidup pada saat sedang gencar gencarnya internet. Ernawati, et al., (2020) Pernyataan dari penelitian tersebut sama dengan hasil penelitian ini, dimana responden mayoritas berumur antara 20-40 tahun.

Mayoritas responden laki-laki sudah pernah mengikuti pelatihan simulasi penanganan bencana erupsi gunung berapi, responden perempuan juga didapatkan hasil lebih banyak yang sudah pernah mengikuti pelatihan simulasi penanganan erupsi gunung berapi. Pada kategori usia 18-20 tahun lebih banyak responden yang menjawab sudah pernah mengikuti pelatihan, kategori usia 21-40 tahun juga didapatkan hasil mayoritas sudah pernah mengikuti pelatihan, usia 40-60 tahun lebih banyak yang menjawab sudah pernah mengikuti pelatihan. Berdasar hasil korelasi pelatihan simulasi penanganan bencana Erupsi Gunung Berapi terdapat hubungan dengan tingkat kesiapsiagaan warga dalam menghadapi bencana Erupsi Gunung Berapi, hal tersebut menunjukkan keterkaitan kesiapan warga dalam menghadapi dampak erupsi bagaimana harus bertindak mulai dari mengetahui tanda-tanda bahaya, arah mata angin, arah jalur evakuasi, kesiapan dalam melakukan pertolongan pertama, bagaimana hidup sehat di pengungsian, bagaimana mengamankan barang-barang berharga secara prioritas, dan sebagainya. Hal tersebut sesuai dengan penelitian (Pratiwi, 2016) bahwa terdapat perbedaan kesiapsiagaan anggota palang merah remaja antara sebelum dan sesudah diberikan pelatihan penanggulangan bencana gempa bumi. Sebelum diberikan pelatihan siswa yang memiliki kesiapsiagaan dengan kategori sangat siap sebanyak 3 anak, setelah diberikan pelatihan siswa pada kategori sangat siap meningkat menjadi 18 anak.

\section{Tingkat Kesiapsiagaan Secara Umum}

Mayoritas warga belum sepenuhnya dikatakan siap dalam tingkat kesiapsiagaan secara umum. Namun sebanyak 96 orang (43\%) sudah termasuk dalam kategori siap, sementara ada 10 responden (4,6\%) yang masih termasuk dalam kategori kurang. Dari data tersebut apabila masyarakat diberikan pelatihan berupa simulasi penanganan bencana erupsi gunung berapi, karena kesiapsiagaan warga yang baik akan mengurangi dampak kerugian dari bencana erupsi gunung berapi. Hal ini sejalan dengan penelitian Saanun, et al (2017) terkait pengaruh penyuluhan kesehatan terhadap kesiapsiagaan dalam menghadapi bencana, menunjukkan tingkat kesiapsiagaan sebelum dan sesudah penyuluhan pada siswa didapatkan nilai $\mathrm{P}$ value 0,021 maka ada pengaruh penyuluhan kesehatan terhadap kesiapsiagaan dalam menghadapi bencana tanah longsor pada siswa kelas XI SMK Negeri 6 Manado.

Mayoritas responden telah mengetahui pada komponen mengetahui dan memahami status level vulkanik Gunung Berapi Merapi, pada buku pedoman latihan kesiapsiagaan bencana dari BNPB diberikan penjelasan bahwa penting bagi masyarakat yang bertempat tinggal di wilayah KRB (Kawasan Resiko Bencana) untuk mengetahui status gunung api, $\mathrm{Hal}$ tersebut dikarenakan apabila masyarakat mengetahui status gunung berapi akan mempengaruhi tindakan yang harus dilakukan oleh masyarakat KRB (Kawasan Resiko Bencana) yang dikeluarkan oleh BPPTKG (Badan Penyelidikan dan Pengembangan Teknologi Kebencanaan Geologi). Pada saat ini masyarakat KRB telah dimudahkan dalam mengakses atau mengetahui status gunung berapi melalui situs internet dari BPPTKG baik melalui website atau instagram yang selalu memberikan informasi kepada masyarakat.

Komponen mengetahui titik kumpul, rambu, dan jalur evakuasi juga akan sangat penting bagi warga yang menetap di daerah kawasan resiko bencana (KRB) karena apabila warga masih belum mengetahui akan membuat warga terpisah oleh rombongan keluarga. Dalam hal ini sebagian besar responden telah mengetahui dan memahami hal tersebut. 
Dalam buku saku BNPB Tanggap Tangkas Tangguh menghadapi bencana dijelaskan tiga upaya utama dalam menyusun rencana kesiapsiagaan menghadapi bencana, salah satunya adalah warga diwajibkan untuk mengidentifikasi titik kumpul, mengetahui rute evakuasi. Hal ini akan memudahkan warga dalam melakukan evakuasi mandiri, karena jelas nya titik kumpul dan rute evakuasi akan membuat warga tidak kebingungan ketika warga harus berpindah ke tempat yang lebih aman.

Keluarga merupakan organisasi terkecil yang dipimpin oleh kepala keluarga, kesepakatan keluarga akan sangat penitng dalam merencanakan tindakan untuk evakuasi mandiri apabila terjadi erupsi gunung berapi, pada komponen tas siaga bencana keluarga dan sejenisnya banyak warga yang sudah memiliki. Tas siaga bencana keluarga akan sangat penting apabila keluarga harus menetap untuk sementara waktu di barak pengungsian.

Erupsi Gunung Berapi menyebabkan dampak kerugian tidak hanya dari segi material, ekonomi, namun yang paling merugikan adalah segi fisik, menurut Baxter \& Horwell, (2015) dampak kesehatan dari erupsi gunung berapi antara lain asfiksia karena tidak tersuplainya oksigen ke dalam otak, gas gangrene Infeksi jaringan lunak yang disebabkan oleh kontaminasi luka oleh organisme penghasil gas(Clostridium welchii) yang tumbuh subur tanpa adanya oksigen. Tetanus sebagai infeksi jaringantinggi disebabkan oleh kontaminasi luka oleh bakteri Clostridiumtetani. Bakteri dapat menghasilkan toksin karena mempengaruhi sistem saraf, mengakibatkan kejang otot yang tidak disengaja. Tidak ada pengobatan khusus dan kondisinya hampir selalu berakibat fatal.

Namun dari 219 responden masih ada beberapa responden yang menjawab tetap tinggal di rumah nya dengan alasan berbagai hal salah satunya yaitu masih mempercayai petuah petuah tokoh adat, seperti dikatakan dalam penelitian Lestari, et al., (2012) bahwa beberapa warga enggan mengungsi sebelum mbah marijan (almarhum) memberikan instruksi untuk mengungsi.

\section{Tingkat Kesiapsiagaan Bidang Kesehatan Warga}

Responden pada penelitian ini mayoritas mendapatkan nilai dalam kategori cukup yang dipengaruhi oleh beberapa hal, salah satu hal yang paling berpengaruh adalah belum pernah dilakukan pelatihan pertolongan pertama di daerah responden, hanya sebagian kecil responden yang menjawab benar atau dalam kategori baik. Penelitian ini sejalan dengan Dien, et al., (2015) dengan hasil ada pengaruh yang signifikan penyuluhan kesehatan dengan kesiapsiagaan siswa menghadapi gempa bumi pada siswa SMP Kristen Kakaskasen Kota Tomohon. Hasil wawancara dengan kepala dusun Srunen, di Desa Glagaharjo pernah dilakukan simulasi penanganan erupsi gunung merapi termasuk didalamnya penyuluhan di bidang kesehatan, namun tidak semua warga Dusun Srunen mengikuti kegiatan tersebut.

Kader kesehatan merupakan salah satu orang yang berpengaruh terkait hal-hal yang berhubungan terkait kesehatan masyarakat dusun, termasuk dalam kesehatan saat terjadi bencana, kader kesehatan akan memberikan pengalaman yang sudah pernah dilakukan oleh kader kepada masyarakat. Dalam hal ini responden mayoritas menjawab sudah ada kader dan sudah pernah mengikuti pelatihan P3K. penelitian ini sejalan dengan penelitian Fitra Bagus (2015) yang menjelaskan tentang peran modal sosial dalam kebijakan kesiapsiagaan bencana di tingkat komunitas seperti mengambil kebijakan untuk bersama sama memahami terkait kebencanaan, peringatan ancaman Gunung Raung, kebijakan terkait titik kumpul.

\section{Hubungan Pengalaman Mengikuti Pelatihan/Simulasi dengan Tingkat Kesiapsiagaan}

Pada penelitian ini terdapat hubungan yang signifikan antara dilakukannya pelatihan dengan tingkat kesiapsiagaan warga dalam menghadapi Bencana gunung Berapi Merapi. Pada penelitian ini responden yang pernah mengikuti simulasi seperti pada tabel 9, sebanyak 150 orang dengan persentase $68,5 \%$ yang pernah mengikuti simulasi, sebaliknya ada 69 responden atau $31,5 \%$ yang belum pernah mengikuti simulasi. Hal ini sejalan dengan penelitian Feriyanto (2019) yang menunjukkan bahwa pemberian pelatihan penanggulangan bencana berupa simulasi 
dapat meningkatkan perilaku kesiapsiagaan dalam menghadapi bencana. Hal tersebut penting dilakukan untuk menstimulasi masyarakat terkait interaksi dengan lingkungan, kemampuan interaksi menjadi dapat meningkatkan pengalaman pribadi

\section{KESIMPULAN DAN SARAN}

Kesiapsiagaan secara umum masyarakat dalam kategori cukup yang dengan pemahaman tertinggi pada mengetahui level Vulkanik gunung, dan terendah pada pemahaman KRB.

Kesiapsiagaan bidang kesehatan masyarakat dusun Srunen terhadap dampak erusi gunung berapi dalam kategori cukup dengan pemahaman terhadap adanya kader dalam pertologan keagawatan, serta adanya hubungan antara dilakukan pelatihan dalam bentuk simulasi penanganan bencana Erupsi Gunung Berapi dengan tingkat

\section{DAFTAR PUSTAKA}

Adiwijaya, C., 2017. Pengaruh pengetahuan kebencanaan dan sikap masyarakat terhadap kesiapsiagaan menghadapi bencana tanah longsor (studi di Kelurahan Lawanggintung, Kecamatan Bogor Selatan, Kota Bogor). Volume 3.

Amin, A. C., 2017. Kesiapsiagaan Bencana Erupsi Gunung Merapi Pada Siswa SMP Negeri 2 Cangkringan. Program Studi Pendidikan IImu Pengetahuan Sosial Universitas Negeri Yogyakarta.

Baxter, P. J. \& Horwell, C. J., 2015. Impacts of Eruption on Human Health . Dalam: The Encylopedia of Volcanoes. S.I.:Elsevier.

Baxter, P. J. \& Horwell, C. J., 2015.

Impacts of Eruptions on Human Health. The Encyclopedia of Volcanoes.

BNPB, 2012. [Online] Available at: http://www.bnpb.go.id/ [ Diakses 5 November 2019].

BNPB, 2014. Rencana Nasional Penanggulangan Bencana 2015-2019. Jakarta: s.n.

Ciottone, G., 2016. Ciottone's Disaster Medicine. Edisi kedua penyunt. S.I.:S.n.

Departemen Kesehatan, 2006. Pedoman Pengembangan Desa Siaga. Dirjen dalam meningkatkan tingkat kesiapsiagaan bencana. Penelitian ini berhubungan dengan penelitian (Nada, et al., 2020) Bahwa simulasi hospital disaster plan berhubungan dengan tingkat kesiapsiagaan perawat dalam menghadapi bencana.

kesiapsiagaan warga dalam menghadapi bencana erupsi Gunung berapi. Maka diperlukan program pelatihan, sosialisasi, dan koordinasi dengan instansi, lembaga, maupun organisasi non pemerintahan yang menaungi terkait kebencanaan secara berkelanjutan.

Mengingat aktivitas Gunung Merapi sejak tahun 2018 yang berada pada level 2 (Waspada) maka diharapkan warga masyarakat pada KRB untuk lebih meningkatkan lagi terkait kesiapsiagaan secara umum dan kesiapsiagaan bidang kesehatan.

Bina Kesehatan Masyarakat.

Dien, R. J., Kumaat, L. \& Malara, R., 2015. Pengaruh Penyuluhan Kesehatan Terhadap Kesiapsiagaan Menghadapi Bencana Gempa Bumi Pada Siswa SMP Kristen Kakaskasen Kota Tomohon. Jurnal Keperawatan UNSRAT .

Ernawati, Y., Rufii \& Waluyo, D. A., 2020. Komik Digital Ekonomi Untuk Generasi Milenial. Jurnal Education and developmentinstitut Pendidikan Tapanuli Selatan, Volume Vol. 8 No. 2.

ESDM, 2019. [Online] Available at: https://www.esdm.go.id/assets/media / content/

Pengenalan_Gunung_Api.pdf[Diakses 19 November 2019].

Fatmadona, R. \& Sabri, R., 2014. Analisis Faktor yang Berhubungan dengan Rencana Keluarga di Pesisir Pantai Kota Padang dalam Menghadapi Bencana. Ners Jurnal Keperawatan, Volume 10.

Haeriah , S., Nugraha, A. L. \& Sudarsono, B., 2018. Analisis Kerentanan Pada Wilayah Permukiman Akibat Bencana Erupsi Gunung Merapi ( Studi Kasus: Kabupaten Sleman). Volume 7, pp. 
65-74.

Hidayati, D. Et al., 2006. Kajian Kesiapsiagaan Masyarakat dalam Mengantisipasi Bencana Gempa Bumi \& Tsunami. [Online] Available at: http://www.bukue.lipi.go.id/utama.cgi? Lihatarsip\& jans001\& 1273262299 [Diakses 10 Januari 2020].

Hidayati, D. Et al., 2006. LIPIUNESCO/ISDR. [Online] Available at: http://www.bukue.lipi.go.id/utama.cgi? Lihatarsip\& jans001\& 1273262299 [Diakses 10 Januari 2020].

IFRC International Federation of Red Cross and Red Crescent Societies, 2019. IFRC Disaster Preparedness. [Online] Available at: https:// media.ifrc.org/ ifrc/what-we-do/disaster-and-crisismanagement/disaster-preparedness/ [Diakses 28 Oktober 2019].

International Federation of Red Cross and Red Crescent Societies (IFRC) , 2019. About Disaster Management. [Online] Available at: https://www.ifrc.org/ en/what-we-do/disaster-

management/about-disaster-

management/ [Diakses 10 Oktober 2019].

Kemenkes RI, 2015. Pedoman Pemberdayaan Masyarakat dalam Penanggulangan Krisis Kesehatan. S.I.:S.n.

Lenntech, t.thn. Volcanin Eruptions and Environment. [Online] Available at: https://www.lenntech.com/volcaniceruptions-environment.htm [Diakses 30 Oktober 2019].

Lestari, P., Prabowo, A. \& Wibawa, A., 2012. Manajemen Komunikasi Bencana Merapi 2010. Jurnal IImu Komunikasi, Volume Vol 10 No. 2.

M., Amin, M. K. \& Astuti, R. T., 2019. Kesiapsiagaan Masyarakat Di Desa Dukun Kecamatan Dukun Kabupaten. Wiraraja Medika, Volume Vol. 9 No. 2, p. $35-41$.

Mcisaac, J. H. \& Berkow, L. C., 2013. Disaster Preparedness, Cardiopulmonary Rescucitation, and Airway Management. Dalam: Benumof and Hagberg's Airway Management. S.I.:Elsevier, pp. 692-704.e2.
Authority,(NDMA)2014. National Policy Guidlines on Vulnerable Groups in Disasters. Pakistan : National Disaster Management Authority. [Online] Available at: www.ndma.gov.pk[Diakses 10 Januari 2020].

Ni Made, P., Sahrir, S. \& Maryam, L., 2018. Gambaran pengetahuan dan sikap tentang kesiapsiagaan bencana pada bidang kedokteran kesehatan (BIDOKKES) polda Maluku tahun 2018. Desember.Volume 3.

Nursalam, 2015. Metodologi Penelitian IImu Keperawatan. Jakarta: Salemba Medika.

OCHA (Office for the Coordination of Humanitarian Affairs) , 2019. Https://www.unocha.org/. [Online] Available at: https://www.unocha.org /sites/unocha/files/dms/Disaster\%20G uide\%20Bahasa.pdf [Diakses 9 Januari 2020].

Permana, S. A., Setyowati, D. L., Slamet, A. \& Juhadi, t.thn. Eling Lan Waspodo Sebagai Persepsi Masyarakat Dalam Menghadapi Ancaman Erupsi Merapi di Wilayah Cangkringan Sleman Yogyakarta.

Purnama, S. G., 2017. Modul Manajemen Bencana. Bali : Fakultas Kedokteran Universitas Udayana Program Studi Kesehatan Masyarakat.

Pusat Data Informasi Badan Nasional Penanggulangan Bencana, 2017. Buku Saku Tanggap Tangkas Tangguh Menghadapi Bencana. 1st penyunt. Jakarta: Pusat Data Informasi dan Humas BNPB.

Saanun, F., Kumaat, L. T. \& Mulyadi, 2017. Pengaruh Penyuluhan Kesehatan terhadap Kesiapsiagaan Dalam Menghadapi Bencana Tanah Longsor Pada Siswa Kelas XI SMK Negeri 6 Manado. E-Journal Keperawatan (e$K p)$.

Saragih , B. Et al., 2014. Asmarandana Merapi : Narasi Ketangguhan OrangOrang Merapi. S.I.:BNPB, UNDP, DR4, MRR.

Sari, M. M., 2017. Aplikasi Peta Kawasan Rawan Bencana (KRB) Dalam Analisa Sebaran Korban Erupsi Gunung Api Merapi 2010. Jurnal Spasial, Volume 1.

Sartika, E., Munadi, K. \& Mutiawati, E., 
2017. Penguatan Peran Posyandu Dalam Meningkatkan Ketahanan Masyarakat Terhadap Bencana Tsunami di Wilayah Pesisir Kota Banda Aceh Menggunakan Pendekatan Knowledge Management. Jurnal ilmu kebencanaan, Volume Vol 4 No. 4.

Setiawati, I., Utami, G. T. \& Sabrian, F., 2020. Gambaran Pengetahuan Dan Sikap Perawat Tentang Kesiapsiagaan Pelayanan Kesehatan Dalam Menghadapi Bencana Banjir. Jurnal Ners Indonesia, Volume 10.

Setyaningrum, N. \& Rumagutawan, R., 2018. Tingkat pengetahuan penanggulangan bencana dan kesiapsiagaan bencana gempa bumi pada kepala keluarga di Dusun Kiringan Canden Jetis Bantul Yogyakarta. Health Sciences and Pharmacy Journal, Volume Vol. 2 No. 3.

Sholehah, I., 2017. Upaya Rehabilitasi Pasca Bencana Oleh MDMC Studi Kasus Banjir Garut Jawa Barat.

Sugara, Alatas , S., Farida, H. \& Ani , S., 2018. Hubungan Pengetahuan Dengan Sikap Kesipsiagaan Masyarakat Menghadapi Erupsi Gunung Kelud Pada Fase Mitigasi. Volume 3, p. 11.
Sugiyono , 2016. Metode Penelitian. Bandung: Alfabeta.

Sulistyaningsih, W. \& Widyanta, A., 2018. Erupsi Tiada Henti Gunung Sinabung: Gambaran Ketangguhan dan Kesadaran Bencana Pada Penyintas. Volume 9.

Syahrizal, Karim, D. \& Nauli, F. A., 2019. Hubungan Pengetahuan Perawat terhadap universal precautions dengan penerapan universal precaution pada tindakan pemasangan infus.. Jurnal Online Mahasiswa, Volume Vol 2 (1).

Tekeli, Y. S., 2006. Public Health and Natural Disaster: Disaster Preparedness and Response in Health System. 31 May .

Tjandra, K., 2017. Empat Bencana Geologi Yang Mematikan. Yogyakarta: Gadjah Mada University Press. 